\title{
Study of Slow Moving Landslide Umka Near Belgrade, Serbia (IPL-181)
}

\author{
Biljana Abolmasov, Miloš Marjanović, Svetozar Milenković, \\ Uroš Đurić, Branko Jelisavac, and Marko Pejić
}

\begin{abstract}
The IPL project No 181 titled "Study of slow moving landslide Umka near Belgrade" started in November 2012. The study area is located on the right bank of Sava River, $25 \mathrm{~km}$ south west of Belgrade, Serbia. The basic objective of the Project was to enable the analysis, correlation and synthesis of data obtained from various phases of investigation of Umka landslide after 35 years of research. Apart from this, the analysis of data from monitoring conducted during certain phases of research was compared with data from automated GNSS monitoring over the last six years, although during numerous investigations various research methods were used for research and monitoring. The project was focused on: analysis of previous detail site investigations and field instrumentation from 1990-2005, analysis of aerial photos and orthophoto images from 1957-2010, analysis of automated GNSS monitoring results from 2010 to end of the Project and analysis of precipitation and levels of the Sava River. Project beneficiaries are local community and local and regional authorities. In this paper we will present results of the proposed project targets performed by Project participants.
\end{abstract}

\author{
Keywords \\ Landslide • Slow moving • Active • Deep seated
}

\section{Introduction}

The Republic of Serbia is located on the Balkan Peninsula in south-east Europe, covers an area of $88,361 \mathrm{~km}^{2}$ and has a population of 7,181,505 (http://stat.gov.rs) (Fig. 1). Because of its complex geological history and terrain composition, and morphological and climate characteristics, $15.08 \%$ of Serbian

B. Abolmasov $(\bowtie) \cdot$ M. Marjanović

Faculty of Mining and Geology, University of Belgrade, Đušina 7, 11000 Belgrade, Serbia

e-mail: biljana.abolmasov@rgf.bg.ac.rs

M. Marjanović

e-mail: milos.marjanovic@ @rgf.bg.ac.rs

S. Milenković · B. Jelisavac

The Highway Institute, Kumodraška 257, 11000 Belgrade, Serbia

e-mail: svetozar.milenkovic@highway.rs territory is affected by landslides (active, suspended and dormant) (Dragićević et al. 2011). The greatest numbers of landslides are in Tertiary and Quaternary sediments. Tertiary sediments in Serbia are prevalent in the Pannonia basin and its northerly rim, as well as in remains of isolated lake basins in the central region south of the Sava and Danube rivers. Around $18 \%$ of Serbian territory is underlain by Neogene

B. Jelisavac

e-mail: branko.jelisavac@highway.rs

U. Đurić · M. Pejić

Faculty of Civil Engineering, University of Belgrade, Bul Kralja

Aleksandra 84, 11000 Belgrade, Serbia

e-mail: udjuric@grf.bg.ac.rs

M. Pejić

e-mail: mpejic@grf.bg.ac.rs 
Fig. 1 Geographical position of the Republic of Serbia within Europe and the Balkan Peninsula



sediment complexes, with clays, marls, soft limestones, sands and gravels in a variety of spatial ratios. In terrains underlain by the Tertiary complexes, more than $25 \%$ of the territory is affected by landslides (Abolmasov et al. 2015).

Especially interesting are the areas of outer Belgrade and slopes of the right banks of the Sava and Danube rivers, which are known for their instability. Luković (1951), Vujanić et al. (1981, 1984), Lokin et al. (1988), Rokić et al. (1998, 2002), Ćorić et al. (1994, 1996) have all written about this phenomenon. The basic cause of the instability is the complex geological and morphological evolution of the terrain, further influenced by intensive anthropogenic activity, so many dormant landslides have reactivated and many new ones became active as well. According to the latest landslide inventory from 2010, which includes the inner area of the General Plan of Belgrade and covers an area of $437 \mathrm{~km}^{2}$ (1/3 of the total area of the city), over $30 \%$ of the territory is composed of active and suspended landslides (Lokin et al. 2010).

The initiative to collaborate with the International Consortium on Landslides was started in September 2009. The faculty of Mining and Geology of the University of Belgrade became a member of ICL in 2011, and a member of the ICL Adria-Balkan Network in 2012 (Mihalić Arbanas et al. 2013). In March 2012, the Faculty of Mining and Geology and The Highway Institute applied for an IPL project and during the 7th Session of IPL-GPC in Paris in 2012, a joint project number 181 was approved. It was entitled "Study of
Slow Moving Landslide Umka near Belgrade Serbia”. This paper will show results obtained during four years of Project conduct, as described in the project plan and program.

\section{Project Description}

The basic objective of Project 181: "Study of slow moving landslide Umka near Belgrade, Serbia" was to analyse, correlate and synthesise data obtained from various phases of investigation after 35 years of research. Apart from this, the analysis of data received from geotechnical monitoring conducted during certain phases of research would be compared with data from automated GNSS monitoring over the last six years. Synthesis of research results would help define the mechanism and dynamics of movement of this large active slow landslide, with the objective of proposing adequate remedial measures. Project results would also aid a better understanding of other landslides on the right banks of the Sava and Danube.

The Project is organized by the University of Belgrade, Faculty of Mining and Geology and Faculty of Civil Engineering and The Highway Institute Belgrade. University, with Institute staff providing all necessary documentation for Project finalization. Maintenance of equipment will be organized by both institutions. Project Leader is Associate Professor Biljana Abolmasov from University of Belgrade, 
Faculty of Mining and Geology. Core members of the Project are: Svetozar Milenković, MSc, Branko Jelisavac, MSc, Uroš Djurić, Ph.D. student, and Assistant Professor Miloš Marjanović.

\section{Results}

\section{Study Area}

Umka landslide is located in the territory of Belgrade, Municipality of Čukarica, in the right meander of the Sava River (Fig. 2). The Umka landslide has been investigated in detail for a number of years, leading to extensive geotechnical documentation, as well as the publication of a great number of papers in the last 35 years. The greatest amount of research was conducted to prepare technical documentation for various phases of design and planning of the E-763 motorways, whose route would cross the landslides of Umka and Duboko. To a lesser extent, research was carried out for urban development in the settlement of Umka. The last phase of research for the level of the preliminary design for the E-763 motorway was completed in 2005, and no further research has been conducted since then, as no remedial measures were taken and the motorway was not built.
Automatic GNSS monitoring was introduced in March 2010 in the body of the Umka landslide as part of the TR36009 Project supported by the Ministry of Education, Science and Technological Development of the Republic of Serbia (Abolmasov et al. 2012b). The rates of displacement, oscillation of the levels of the Sava River, as well as hydro-meteorological parameters (type and intensity of precipitation) have been followed daily since then.

\section{General Landslides Features}

Umka landslide is in the shape of a triangular fan, around $900 \mathrm{~m}$ long and $1450 \mathrm{~m}$ wide at the toe, with a total surface area of around $1.8 \mathrm{~km}^{2}$, an average depth of $14 \mathrm{~m}$ and with a total volume of approximately $14,000,000 \mathrm{~m}^{3}$. The average inclination of the slope is $9^{\circ}$, apart from the main scarp zone and minor scarps where it can reach up to $25^{\circ}$. The main scarp of the landslide rises up $25 \mathrm{~m}$. The left flank has developed a distinct side scarp, while the right flank of the landslide is concealed along the zone of the local road. The landslide is traversed by numerous secondary scarps of $1-10 \mathrm{~m}$ in height. The toe of the landslide is beneath the water level of the Sava River. Comparative morphological analysis of the orthophoto images from 1957 to 2010
Fig. 2 Orthophoto image of Umka landslide

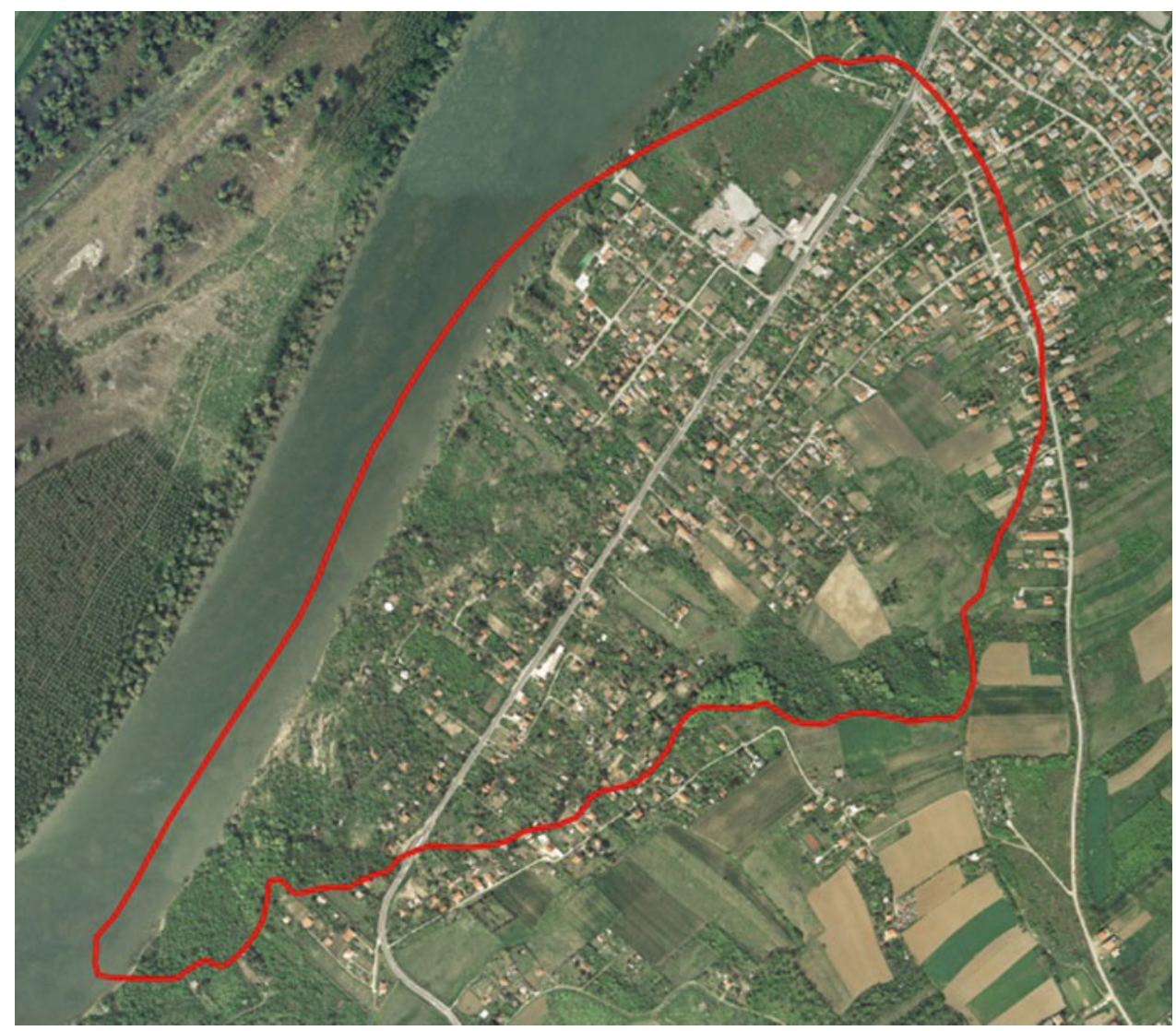


Fig. 3 Results of comparative morphological analysis of DEMs from 1957 to 2010

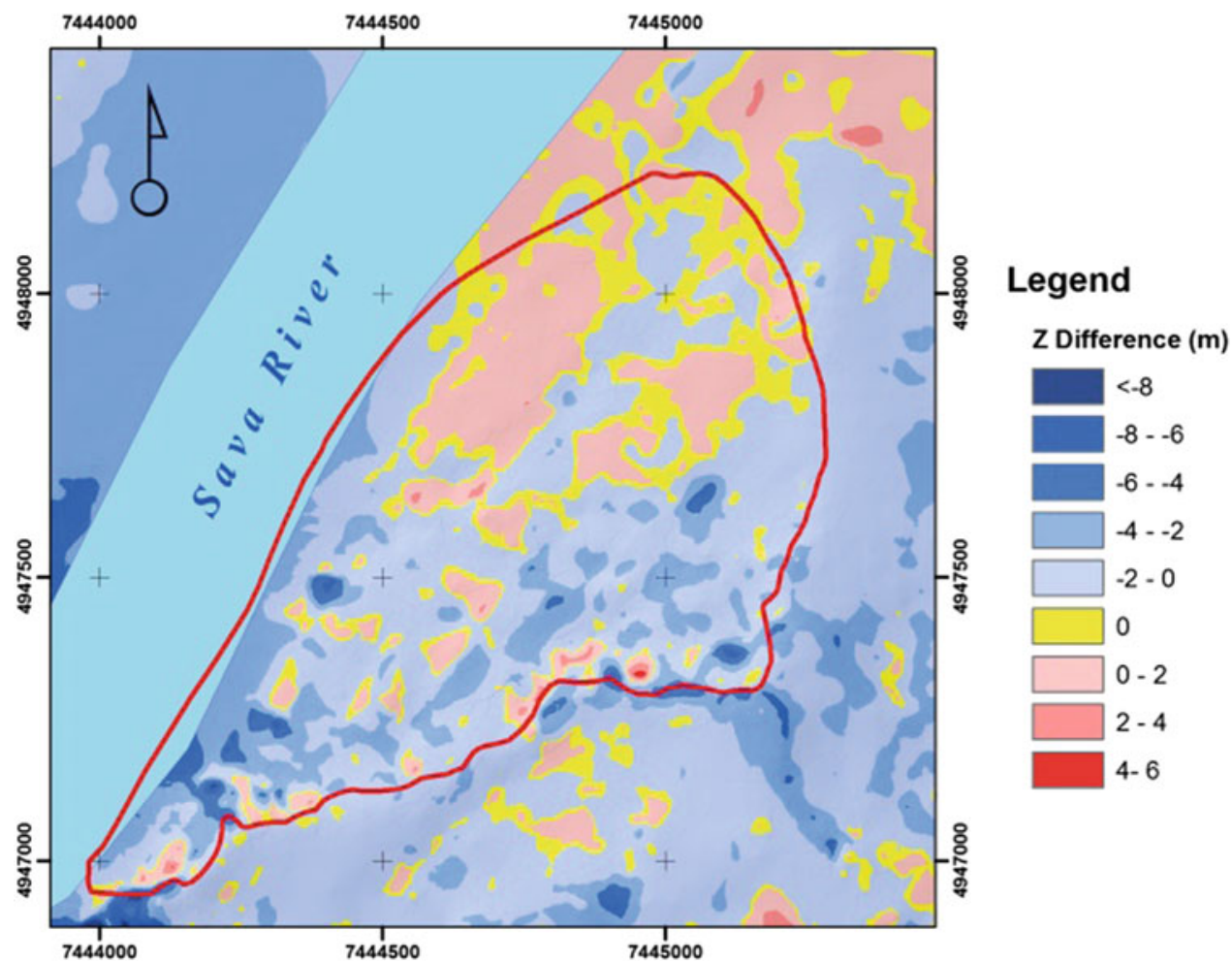

indicate a clear mass deficit in the zone of the frontal scarp and secondary scarps, i.e., enlargement of the landslide body in the toe (Abolmasov et al. 2012a, 2015) (Fig. 3).

The geological setting of the terrain is composed of Neogene and Quaternary sediments. Neogene sediments are represented by silty-clay and massive Pannonian marls $\left(\mathrm{M}_{3}^{2} \mathrm{~L}\right)$ over $200 \mathrm{~m}$ thick. Quaternary sediments are represented by loess $\left(\mathrm{Q}_{2} \mathrm{l}\right)$ and diluvial clays $\left(\mathrm{Q}_{2} \mathrm{dl}\right)$, which form a relatively thin cover $(2-15 \mathrm{~m})$ over the Pannonian marls.

The upper $25 \mathrm{~m}$ of the Pannonian marls is altered to clayey marls $\left(\mathrm{M}_{3}^{2} \mathrm{GL}\right)$ and represents the weathered crust of the bedrock. The contact of these two units, i.e., the contact of marly clays $\left(M_{3}^{2} G L\right)$ and fresh gray marls $\left(M_{3}^{2} L\right)$ is where the principal (deepest) sliding surface was developed. As determined by engineering-geological mapping and confirmed by inclinometer measurements, it is not a uniform surface, but instead can be segregated into three parts that define three separate blocks of the landslide body (blocks A, B, C) (Fig. 4). The deepest displacements have been registered in block A, with a maximum depth of $26 \mathrm{~m}$. The type of movement is translational, with a total shift during the period March-May 2005 recorded by inclinometers measurements of over $6 \mathrm{~cm}$. The landslide depth varies from 4 to $26 \mathrm{~m}$. Numerous secondary scarps and shallow slip planes that additionally separate certain blocks, and which are visible on the terrain surface, have also been mapped along the Sava River banks (Fig. 5).
As a consequence, groundwater distribution is complexly structured. It is usually scattered in hydraulically isolated accumulations, i.e., isolated free-level aquifers formed in the depletion zone, from the ground surface to a depth of 6-8 m, which was confirmed by piezometer observations during 1991-1993 (Vujanić et al. 1995). Very high levels of groundwater were recorded in boreholes and observation wells during January-August 2005 (Jelisavac et al. 2006). In the middle and foot sections of the landslide, the water was almost at the surface and in many locations was flowing diffusely. There is no other data of continuously monitoring of groundwater levels between these periods (Vujanic et al. 1995; Jelisavac et al. 2006).

\section{Material Properties}

To characterize the colluvium and bedrock sediments in terms of its implications for slope stability, an extensive number of laboratory tests were carried out on more than 200 samples, both disturbed and undisturbed. The focus of the testing was on the main physical and mechanical characteristics (grain size distribution, natural water content, unit weight, degree of saturation, Atterberg limits and strength parameters). All the values of available geotechnical parameters from the laboratory tests are plotted against depth, on the triangle diagram and on the A-line plasticity 


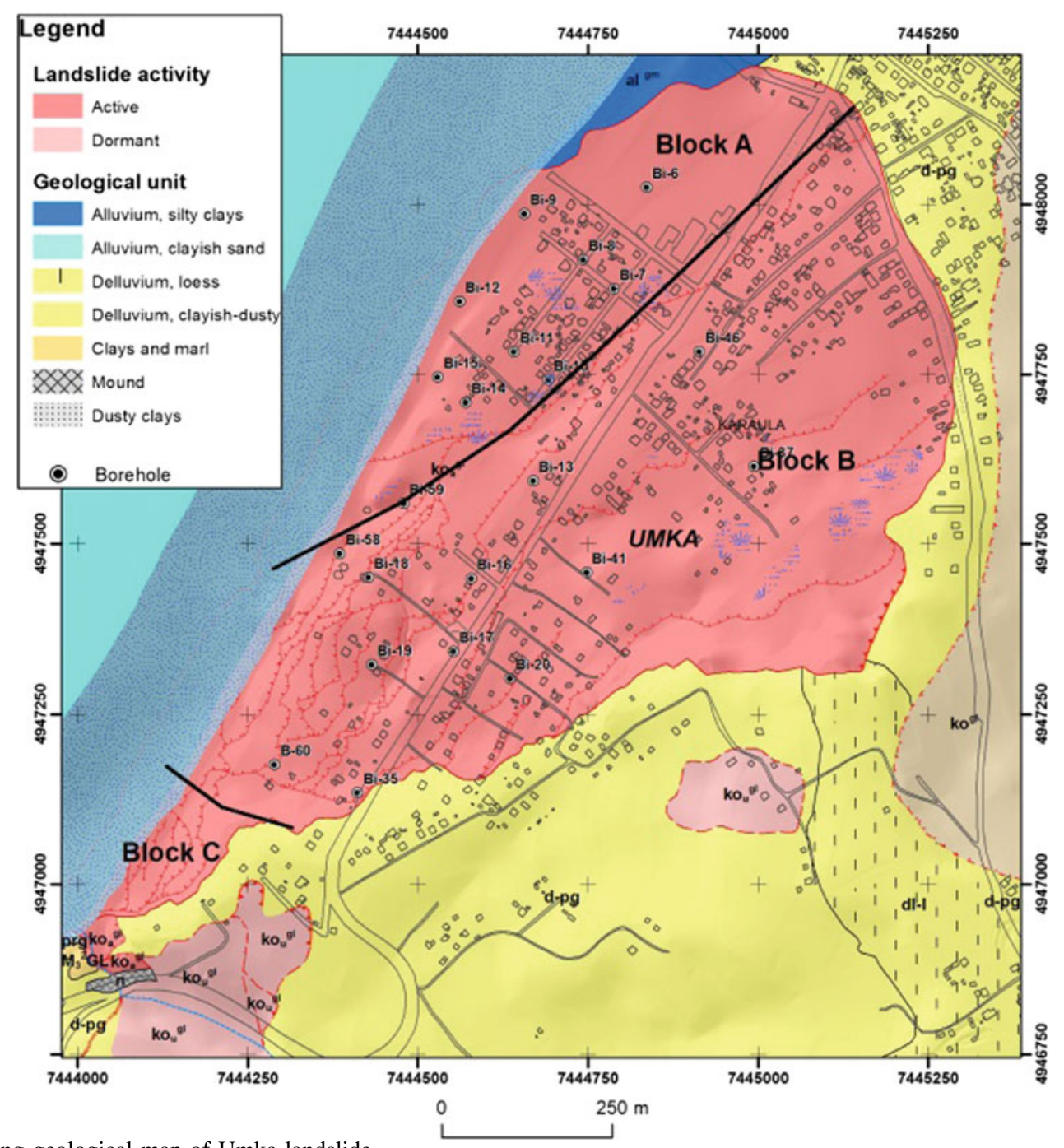

Fig. 4 Engineering geological map of Umka landslide

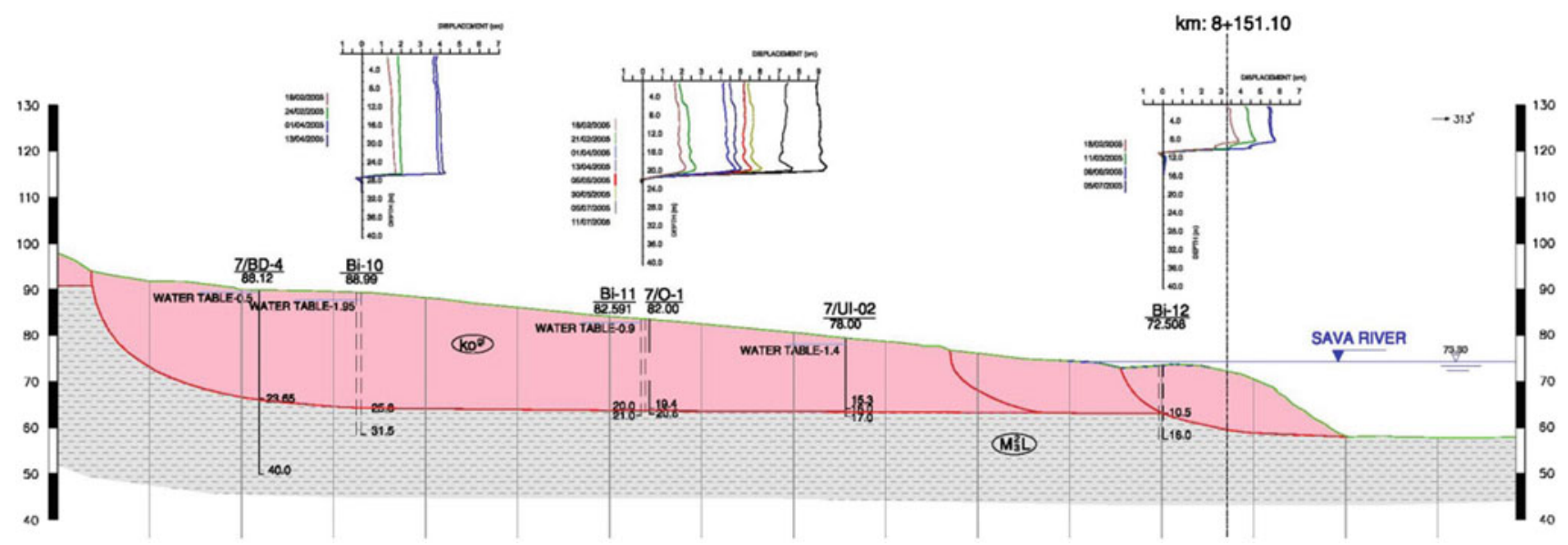

Fig. 5 Engineering geological cross section of Umka landslide toe-Block A 
chart (Abolmasov et al. 2015). Because of the large area and different depths of the landslide, the geotechnical soil parameters show substantial heterogeneity. For the same reason, sharp differences in many physical-mechanical properties between the colluvium mass and the bedrock are not apparent. The drained residual friction angles measured in shear tests ranges from 4 to 21.5 degrees, reflecting the large heterogeneity of the material properties too. These results were compared with previously published correlations based on Atterberg limits and residual friction angle, and residual values are inside the literature correlations (Abolmasov et al. 2015).

\section{Landslide Mechanism and Dynamics}

Umka landslide is a result of prolonged erosion during migration and deepening of the Sava River riverbed from Holocene to the present day. Therein, different paleoecological (primarily paleoclimatic) conditions alternated throughout its recent geological history. In these conditions, the weathering crust of grey Pannonian marls deepened, and because of the lowering of erosion base level and increased erosion of the slope banks, Quaternary sediments - primarily loess, are almost completely absent in the landslide area. Narrowing of the riverbed and its deepening in the meander curve remained the basic cause of the landslide activity. The specific groundwater regime, i.e. the complex system of isolated groundwater bodies within the landslide volume, contributed to the present mechanisms of movement, additionally compounded by numerous secondary movements within certain blocks. Due to the deep sliding surface, intensification of displacement and secondary movements occur during long-term precipitation or sudden snow thaw. These are also the periods of sudden surges and subsequent drops in the water level of the Sava River, which is described as a dominant hydraulic triggering factor.

The dynamics of the landslide are not easy to determine, as there has been no complete or continuous monitoring over a longer period, as would be required for such a complex and large landslide. Based on the analysis of inclinometer readings during 2005, which was also recorded as one of the years when the landslide activity was more intensive, the following conclusions were inferred. A total of 24 inclinometers were installed during February 2005, and depending on their spatial layout in blocks $\mathrm{A}$ and $\mathrm{B}$, the majority of them were discontinued in the following two months, while some remained functional until July 2005. The greatest displacements were recorded in block $\mathrm{B}$, where the inclinometers were discontinued after only two month of observation (Jelisavac et al. 2006; Abolmasov et al. 2015). Also in block A, a sliding plane was registered at $26 \mathrm{~m}$, and greatest displacement also occurred in March-April 2005. Similar shifts were measured in all 24 inclinometers. At the same time, the movements are synchronised with increases of the levels of the Sava River and an increase in the average daily air temperature, which caused thawing of $30 \mathrm{~cm}$ of snow in $24 \mathrm{~h}$ (Abolmasov et al. 2014).

Automated continuous real-time GNSS monitoring was established in March 2010 (Abolmasov et al. 2012b, 2013). Simultaneously, the levels of the Sava River were observed in near-real time, i.e., on daily basis, as well as the average daily temperature and type and amount of precipitation. After the monitoring system was established, during the period between March 2010 and October 2013, the landslide velocity varied, with distinctive acceleration and deceleration phases. The highest velocities of movement were recorded in March-July 2010, when the total rainfall amounted to one third of the total annual rainfall. Simultaneously with the unusually high rainfall, a rise and then an abrupt fall in the level of the Sava River were recorded, which caused $2 \mathrm{~cm}$ displacement in a single day (Abolmasov et al. 2012b). Similar behaviour was registered in December 2010 when a high level of the Sava River caused an acceleration in landslide velocity from $0.54 \mathrm{~mm} /$ day to $1.16 \mathrm{~mm} /$ day, which lasted until February 2011. Deceleration started in May 2011, during the drought period and extremely low levels of the Sava River. Cumulative displacements from March 2010 up to December 2013 equalled $65 \mathrm{~cm}$ in the easterly direction (y coordinate), $42 \mathrm{~cm}$ in the northerly direction ( $x$ coordinate), and a subsidence of $22 \mathrm{~cm}$ ( $\mathrm{z}$ coordinate). The displacement vector of the monitoring point clearly shows a downhill trend towards the Sava River, with a relatively uniform constant linear movement (Fig. 6).

During extreme floods in Serbia in May 2014, the GNSS monitoring system was broken and it was installed again in September 2014. The structure of the automated monitoring system (Abolmasov et al. 2012b) was kept, but the monitoring point-station on Block B was moved $10 \mathrm{~m}$ to the SW to another position.

Analysing the nature of the 3-D movements during September 2014-July 2016, it is clear that trend is close to linear, which confirms that there were no sudden slides in the 22-month monitoring period, except acceleration of movement between February-May 2015. For the rest of the monitoring period, the velocity of movement slowed down. The cumulative displacement from September 2014-July 2016 reached $40 \mathrm{~cm} \mathrm{E,} 25 \mathrm{~cm} \mathrm{~N}$ and $15 \mathrm{~cm}$ in height (Fig. 7). One can also conclude that Umka landslide has had a relatively constant velocity of movement towards the Sava River during the new GNSS point position monitoring period, as well as during previous research (Abolmasov et al. 2015). 


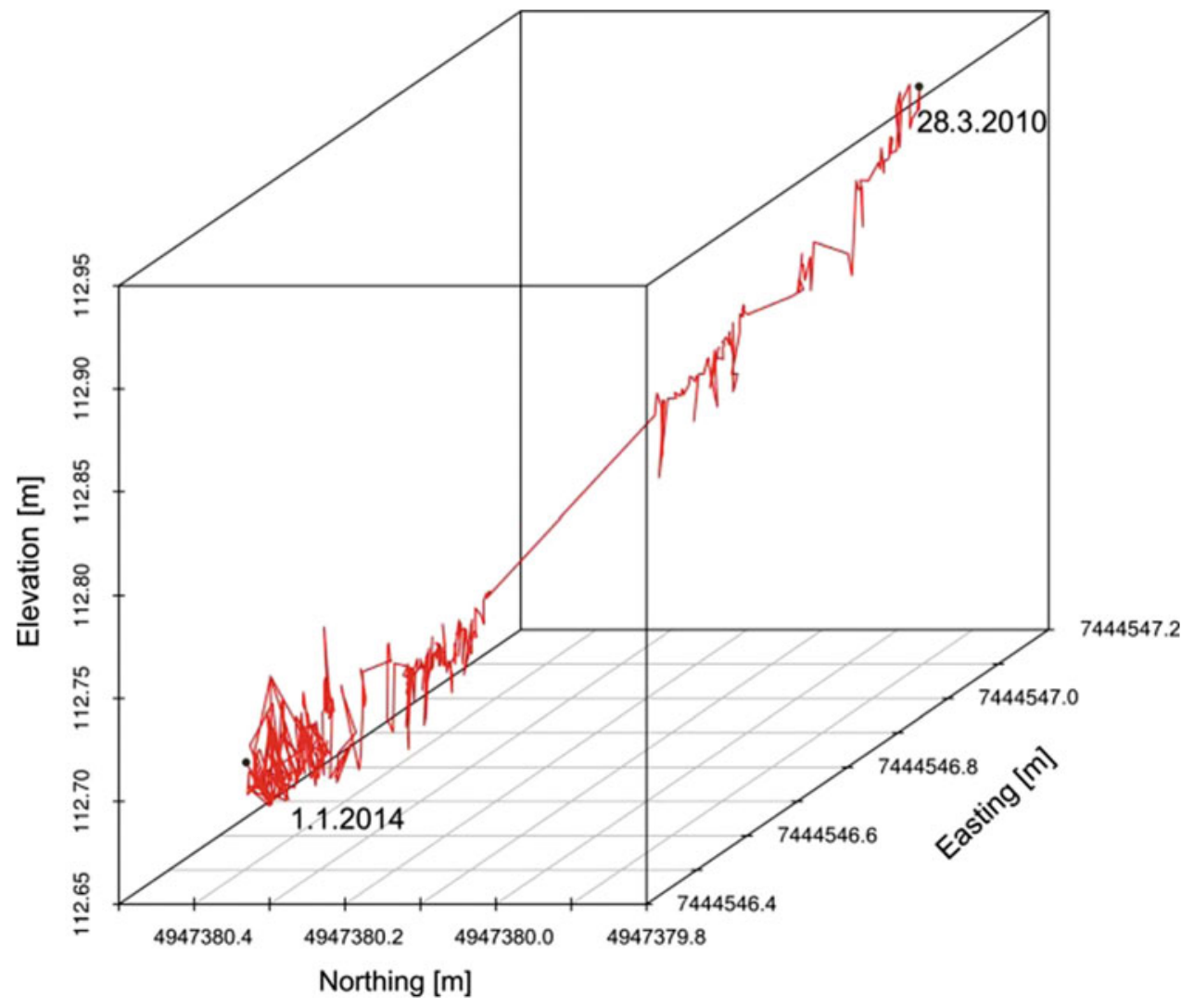

Fig. 6 Three-dimensional displacement vector of a GNSS monitoring station from 2010 to 2014

Fig. 7 Three-dimensional displacement plot from September 2014 to July 2016

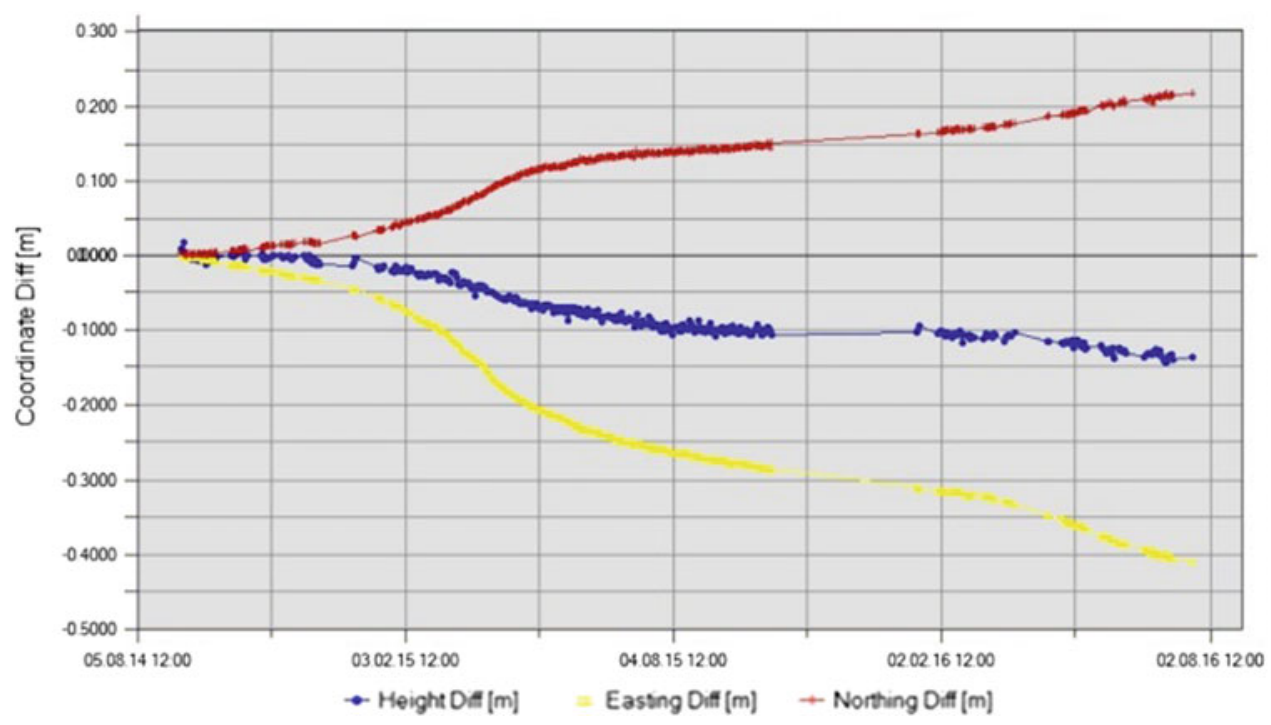




\section{Conclusion}

The analysis of field investigations, laboratory results and monitoring data confirmed that Umka can be characterized as a compound landslide in stiff fissured clayey marls in active stage, with alternating phases of intensive and slow movements, while the velocity can be characterized as slow to very slow (Abolmasov et al. 2015).

Further research during the IPL 181 Project will focus on details of $\mathrm{A}, \mathrm{B}$ and $\mathrm{C}$ block movement mechanisms and their synchronisation with data on the triggers (the Sava River level and rainfall) and correlation with actual GNSS monitoring results. Also, coupling current surface real-time monitoring GNSS system with a near-real time inclinometer measurements is also planned in the nearer future. This would support the geotechnical model and reveal the connection between ground displacement and actual displacement on the slip surface level. Finally, the continuation of the current monitoring campaign will be further support for the geotechnical model development and evaluation of additional numerical analyses.

Acknowledgements The IPL Project 181 would have not been possible without support from VekomGeo d.o.o and Republic Hydrometeorological Service of Serbia. The research was supported by the Ministry of Education, Science and Technological Development of the Republic of Serbia Project No TR 36009.

\section{References}

Abolmasov B, Đurić U, Pavlović R, Trivić B (2012a) Tracking of slow moving landslides by photogrammetric data-a case study. In: Eberhardt E, Froese C, Turner K, Leroueil S (eds) Proceedings of the 11th International and 2nd American symposium on landslides and engineered slopes, Banff, Canada, 3-8 June 2012, vol 2, Taylor \& Francis Group, London, pp 1359-1363

Abolmasov B, Milenković S, Jelisavac B, Vujanić V, Pejić M, Pejović M (2012b) Using GNSS sensors in real time monitoring of slow moving landslides-a case study. In: Eberhardt E, Froese C, Turner K, Leroueil S (eds) Proceedings of the 11th International and 2nd American Symposium on landslides and engineered slopes, Banff, Canada, 3-8 June, 2012, vol 2, Taylor \& Francis Group, London, pp 1381-1385

Abolmasov B, Milenković S, Jelisavac B, Vujanić V (2013) Landslide Umka: The First Automated Monitoring Project in Serbia. In: Margottini C, Canuti P, Sassa K (eds) Landslide Science and Practice, vol 2: Early Warning, Instrumentation and Monitoring, Springer, Berlin, pp 339-346
Abolmasov B, Pejić M, Šušić V (2014) The analysis of landslide dynamics based on automated GNSS monitoring. In: Sassa K, Mihalić Arbanas S, Arbanas Ž (eds) Proceedings of the 1st Regional Symposium on landslides in the Adriatic-Balkan Region-1st ReSyLAB 2013, Zagreb 6-9 March 2013, University of Zagreb, Faculty of Mining, Geology and Petroleum Engineering and University of Rijeka, Faculty for Civil Engineering, Zagreb, Croatia, pp 187-191

Abolmasov B, Milenković S, Marjanović M, Đurić U, Jelisavac B (2015) A geotechnical model of the Umka landslide with reference to landslides in weathered Neogene marls in Serbia. Landslides 12 (4):689-702. doi:10.1007/s10346-014-0499-4

Ćorić S, Božinović D, Vujanić V, Jotić M, Jelisavac B (1994) Slope instability analysis in Neogene clays and marls. In: Lisboa Portugal, Oliveira R, Rodrigues LF, Coelho AG, Cunha AP (eds) Proceedings of 7th International IAEG Congress, 5-9 Sept 1994, vol 3, Balkema, Rotterdam, pp 1759-1770

Ćorić S, Božinović D, Vujanić V, Jotić M, Jelisavac B (1996) Geotechnical characteristics of old landslides in Belgrade area. In: Senneset K (ed) Proceedings of the 7th International symposium on landslides, 17-21 June 1996, Trondheim, Norway, Vol 2, Balkema, Rotterdam, pp 689-694

Dragićević S, Filipović D, Kostadinov S, Ristić R, Novković I, Živković N, Anđelković G, Abolmasov B, Šećerov V, Đurđić S (2011) Natural hazard assessment for land-use planning in Serbia. Int J Environ Res 5(2):371-380

Jelisavac B, Milenković S, Vujanić V, Mitrović P (2006) Geotechnical investigations and repair of the landslide Umka-Duboko on the route of motorway E-763 Belgrade-South Adriatic. International Workshop-Prague-Geotechnical days, Prague

Lokin P, Sunarić D, Cvetković T (1988) Landslides in Neogene sediments on the right Danube bank, Yugoslavia. In: Ch Bonnard (ed) Proceedings of the 5th international symposium on landslides, 10-15 July 1988, Lausanne, vol 1, Balkema, Rotterdam, pp 213-217

Lokin P, Pavlović R, Trivić B (2010) Projekat istraživanja terena za izradu katastra klizišta područja Generalnog urbanističkog plana područja Beograda. J.P. Direkcija za građevinsko zemljište grada Beograda (in Serbian). Unpublished material

Luković TM (1951). Važniji tipovi naših klizišta i mogućnosti njihovog saniranja. Geološki Vesnik Savezne uprave za geološka istraživanja, Knjiga IX, Beograd, pp 275-310 (in Serbian)

Mihalić Arbanas S, Arbanas Ž, Abolmasov B, Mikoš M, Komac M (2013) The ICL Adriatic-Balkan network: analysis of current state and planned activities. Landslides 10:103-109. Doi:10.1007/ s10346-012-0364-2

Rokić Lj, Vujanić V, Jotić M (1998). Forecast of the landslide development processes based on the study of erosion processes of rivers in the plains. In: Moore D, Hungr O (eds) Proceedings of 8th International IAEG Congress, 21-25 Sept 1998, Vancouver, Canada, vol 3, Balkema Rotterdam, pp 1485-1491

Rokić Lj, Vujanić V (2002) A contribution on the study of landslide origins in Neogene sediments of Danube river coastal area. In: Rybar J, Stemberk J, Wagner P (eds) Proceedings of the 1st European conference on landslides, Prague, Czech Republic, June 24-26 2002, Balkema Publishers, pp 291-298 
Vujanić V, Jotić M, Jelisavac B, Božinović D, Ćorić S (1995) Sinteza rezultata gotehničkih istraživanja klizišta na Savi: Umka i Duboko. Zbornik radova Drugog simpozijuma Istraživanje i sanacija klizišta, 6-9 juni 1995, Donji Milanovac, pp 335-351 (in Serbian)

Vujanić V, Livada N, Božinović D (1984) On an old landslide in Neogene Clays on the right bank of the Sava near Belgrade.
Proceedings of 4th international symposium on landslides, Toronto, Canada, 1984, vol 2, pp 227-233

Vujanić V, Livada N, Jotić M, Gojković S, Ivković J, Božinović D, Sunarić D, Šutić J (1981) Klizište "Duboko" na Savi kod Beograda. Zbornik radova Simpozijuma istraživanje I sanacija klizišta, Bled 1981. Knjiga 1:119-134 (in Serbian)
Open Access This chapter is licensed under the terms of the Creative Commons Attribution 4.0 International License (http:// creativecommons.org/licenses/by/4.0/), which permits use, sharing, adaptation, distribution and reproduction in any medium or format, as long as you give appropriate credit to the original author(s) and the source, provide a link to the Creative Commons license and indicate if changes were made.
The images or other third party material in this chapter are included in the chapter's Creative Commons license, unless indicated otherwise in a credit line to the material. If material is not included in the chapter's Creative Commons license and your intended use is not permitted by statutory regulation or exceeds the permitted use, you will need to obtain permission directly from the copyright holder. 